\title{
The Decline of Liberalism in Europe and how to Revive it
}

\author{
Jordi Franch Parella \\ Ph.D., Faculty of Social Sciences at Manresa, Universitat de Vic \\ - Universitat Central de Catalunya (UVic-UCC), Manresa, Spain \\ e-mail: jfranch@umanresa.cat
}

\begin{abstract}
The liberal world order has produced immense benefits for Europe and people across the planet. Beginning in the $18^{\text {th }}$ and $19^{\text {th }}$ centuries, liberalism reinforces the natural rights of man to life, liberty and property, and has transformed the world in ways that have improved the material and social circumstances of humankind. But the liberal order that has been in place in Europe since 1945, after two world wars, is showing signs of deterioration. Today, this liberal order is being challenged by a variety of forces. The essence of the European experience is the development of a civilization that considered itself to be a unity and yet was politically decentralized. Former free towns in Italy and the Low Countries became bastions of a self-governing middle class in the Middle Ages. However, with time, states tend to overgrow taking more and more resources, which results in the increase in taxes and public spending, excessive regulation, deficits and public debt. There is a fight between the advocates of two different ideals of the European Union, the non-liberal and the liberal vision. There is a consensus in that the market economy is the system that best produces the most, removing millions of people from poverty. But it is the unequal distribution of the wealth created that is often criticized. We examine the distribution of income, before and after taxes and transfers, concluding that market liberalization does not necessarily lead to increased social inequality. On the other hand, two of the most important threats challenging the liberal order in Europe are populist parties and protectionism. Finally, this paper suggests a way towards a future Europe, deepening the single market and economic integration, but transforming the obsolete and dysfunctional nation-states into other forms of decentralized political units.
\end{abstract}

Keywords: liberalism, Europe, single market, nation-state, decentralization

JEL: O52, P17, P59 


\section{Introduction}

The liberal world order that was created in the aftermath of World War II has produced immense benefits for peoples across the planet. The past 70 years, since the end of World War II, have seen an unprecedented growth in prosperity, taking billions out of poverty. Democratic government, once rare, has spread to many nations around the world, on every continent, for people of all religions and races. And although the period has been marked by war and suffering as well, peace among the great powers has been preserved. There has been no recurrence of the two devastating world wars of the first half of the $20^{\text {th }}$ century. However, the liberal world order that has been in place since 1945 is showing signs of deterioration. The turmoil and multi-sided conflict in the Middle East, Donald Trump's political economy and U.S. trade war with Europe, Russia's military expansionism, the pressures on the liberal political and economic order in Europe, China's growing power, the lack of international consensus on free trade, powerful authoritarian governments and anti-liberal fundamentalist movements, long-term shifts in the global economy with digitalization and robotization, radical Islamic jihadism... All these combine to put this order at risk. This liberal order in Europe is today being challenged by a variety of forces. And the questions we face are whether it is worth defending and whether it is capable of surviving the present challenges.

\section{The meaning of liberalism}

Although freedom and prosperity have replaced tyranny and poverty for hundreds of millions of people around the world since the late $18^{\text {th }}$ century, the economic and political system that historically has made this possible has been highly criticized, condemned and mostly rejected. That economic and political system is liberalism. By liberalism, we do not mean government regulation with wide redistribution of wealth and income. Nor do we mean what is referred to as neoliberalism, in which rent-seeking activities thrive while an interventionist welfare-warfare state and corrupt governments hamper the functioning of a truly competitive market. By liberalism, we refer to economic and political classical liberalism. The liberalism that, beginning in the $18^{\text {th }}$ and $19^{\text {th }}$ centuries, reinforces the natural rights of man to life, liberty and property, and that transformed the world in ways that have improved the material and collective circumstances of humankind. Liberalism implies the belief that social control is best secured by law and impersonal rules rather than by command and personal authority, as well as the belief that there is a sphere of individual rights where the state cannot interfere. Indeed, the existence and the aim of the state is the preservation of these rights. But natural rights are today often ridiculed by intellectuals who frequently find it easier 
to speak about political relativism and ethical nihilism. And yet the modern world of freedom had its origin in them.

The rights that reside in people by their nature as human beings logically precede governments that may or may not respect and enforce these rights. Thinkers such as John Locke and David Hume, William Blackstone and Edward Coke, the Jesuit Juan de Mariana and Adam Smith articulated the meaning of these rights that inspired the U.S. Declaration of Independence in 1776, when they spoke of the self-evident truths that all men are created equal with certain unalienable rights, among which are life, liberty, and the pursuit of happiness.

The object of the classical liberals was to bring about individual liberty in all its interrelated aspects. In the economy, taxes were to be drastically reduced, controls and regulations eliminated, and human energy, enterprise, and markets set free to create and produce in exchanges that would benefit everyone and the mass of consumers. Entrepreneurs were to be free to compete, to develop, to create. Government planners and regulators have neither the wisdom nor the knowledge to direct the complex activities of humanity. An institutional setting of individual liberty, private property and voluntary exchange generates more wealth and coordinated activity than any governmental rule could ever provide. The benefits of such economic liberty made Great Britain and then the United States the industrial powers of the world by the end of the $18^{\text {th }}$ and $19^{\text {th }}$ centuries respectively. Classical liberalism did the same in other parts of Europe, and then in other parts of the world. Population in the West grew far above anything known in the past, yet increased production and rising productivity were giving those hundreds of millions of more people an increasing standard and quality of living. If enough economic freedom and open competition continue to prevail, it is possible that by the end of the $21^{\text {st }}$ century, complete poverty will become a thing of the past everywhere around the world. Peace, too, was the foreign policy of the classical liberals. During the century that separated the defeat of Napoleon in 1815 and the beginning of the First World War in 1914, wars among European countries were infrequent, relatively short, and limited in their physical destruction and taking of human lives. Classical liberals refuse war as it is counterproductive to the interests of all nations, preventing the natural benefits of all people through peaceful production and trade based on an international division of labor.

The decline of liberalism accelerated at the end of the nineteenth century, when statism and intrusive government returned. Led by Bismarck in Prussia, it triggered right-wing collectivism, protectionism, militarism and the forced cartelization of business and industry. A network of controls, regulations and subsidies forged a great partnership of the government with certain privileged elements in industry.

Ralf Dahrendorf (1987, p. 174) remarks that liberal parties declined to the point of insignificance. And, faced with the competition of collectivist ideas, according to Cubeddu (1997, p. 26), liberal parties produced a new breed of political entrepre- 
neurs, i.e. men skilled at mobilizing rent-seeking constituencies that use the state to enhance their economic position. To gain power, these leaders revised the liberal program to the point where it was practically indistinguishable from democratic and social-reformist ideas, ending up by accepting the notion of the state as an instrument for redesigning society to produce particular ends.

Liberalism maintains that individualism is the basis for a cooperative social order. In fact, in Mises' view (2007, pp. 57-58), antiliberal ideologies often mask profoundly antisocial assumptions and the philosophies of collectivism and totalitarianism tend to turn men into slaves of the entity. To quote the Austrian economist (2007, p. 18), "human society is an association of persons for cooperative action. As against the isolated action of individuals, cooperative action on the basis of the principle of division of labor has the advantage of greater productivity. If a number of men work in cooperation in accordance with the principle of the division of labor, they will produce (other things being equal) not only as much as the sum of what they would have produced by working as self-sufficient individuals, but considerably more. All human civilization is founded on this fact."

And nowhere is Max Weber (1949, p. 110) more reasonable than when he speaks out against the aggregate concepts. In fact, the use of the undifferentiated collective concepts of everyday speech is always a cloak for the confusion of thought and action. It is very often an instrument of fraudulent procedures. The result of ignoring Weber's warning is the terminological chaos noted by José Merquior (1991, pp. 45-46), when the Brazilian scholar signals that the meaning of liberalism has changed a great deal. Nowadays, what liberal generally means in continental Europe and Latin America is something quite different from what it means in the United States. Since Roosevelt's New Deal, American liberalism has acquired a social democratic tinge. Liberalism in the United States, in fact, came close to liberal socialism.

\section{The European miracle and its decline}

Europe is rooted in what economic historians sometimes call "the European miracle". Liberalism can be viewed as the emerging ideological and political aspect of that miracle. The essence of the European experience is that a civilization developed that considered itself to be a unity and yet was politically decentralized. The history of the continent devolved into a mosaic of separate and competing jurisdictions and polities whose internal divisions themselves resisted central control. There was, in other words, a type of laissez-faire built into Europe (Hall 1987, p. 55). The relative ease of "exit" and sustained military competition furnished princes with strong incentives to abstain from confiscations and other violations of property rights. In this process, a major role was played by the free towns in Italy, the Low Countries, the Hanseatic League and Germany in the Middle Ages. 
Capitalism flourished earliest in those areas where the central State was weak or nonexistent. The society of status gave way, at least partially, to the society of contract; the military society partially gave way to the protoindustrial society. Liberalism indeed brought to the Western world not only liberty, the prospect of peace, and rising living standards of an industrial society, but also hope in the ever-greater progress that lifted the mass of mankind out of its age of stagnation and despair (Boettke 1994).

Most important, and unique to Europe, was the existence of a powerful, independent, international Church. A critical development was the creation by Pope Gregory VII in the eleventh century of a powerful "corporate, hierarchical church independent of emperors, kings, and feudal lords," and which was thus capable of foiling the relentless power-seeking of temporal authority (Berman 1983, pp. 49-76). In a major synthesis, Law and Revolution, Berman highlights that "perhaps the most distinctive characteristic of the Western legal tradition is the coexistence and competition within the same community of diverse legal systems. It is this plurality of jurisdictions and legal systems that makes the supremacy of law both necessary and possible" (Berman, p. 10).

The great English scholar, A.J. Carlyle, in the conclusion of his monumental study of political thought in the Middle Ages, summarized the basic principles of medieval politics: that all (including the king) are bound by law; that a lawless ruler is not a legitimate king, but a tyrant; that where there is no justice there is no commonwealth; and that a contract exists between the ruler and his subjects (Carlyle and Carlyle 1950, pp. 503-526). Popular rights, above all, protection against arbitrary taxation, were defended by representative assemblies. In the Magna Carta, obtained from King John in 1215, the first signatory was Stephen Langton, Archbishop of Canterbury.

From Adam Smith, little else is requisite to carry a State to the highest degree of opulence from the lowest barbarism but peace, easy taxes, and a tolerable administration of justice; all the rest being brought about by the natural course of things. All governments which thwart this natural course are unnatural and oppressive (Stewart 1996, p. 68).

But the liberal program of establishing a strictly limited state conceals a fundamental contradiction and, in the nature of things, inevitably makes way for a state armed with all-embracing powers. The state grows without limits. This has been persuasively argued by Hans-Hermann Hoppe, who asserts that "contrary to the original liberal intent of safeguarding liberty and property, every minimal government has the inherent tendency to become a maximal government" (Hoppe 2001, pp. 221-238). Considering long-term trends, public spending and taxes increase substantially. More and more resources are appropriated by the government and a higher share of income is needed to feed the public sector. 


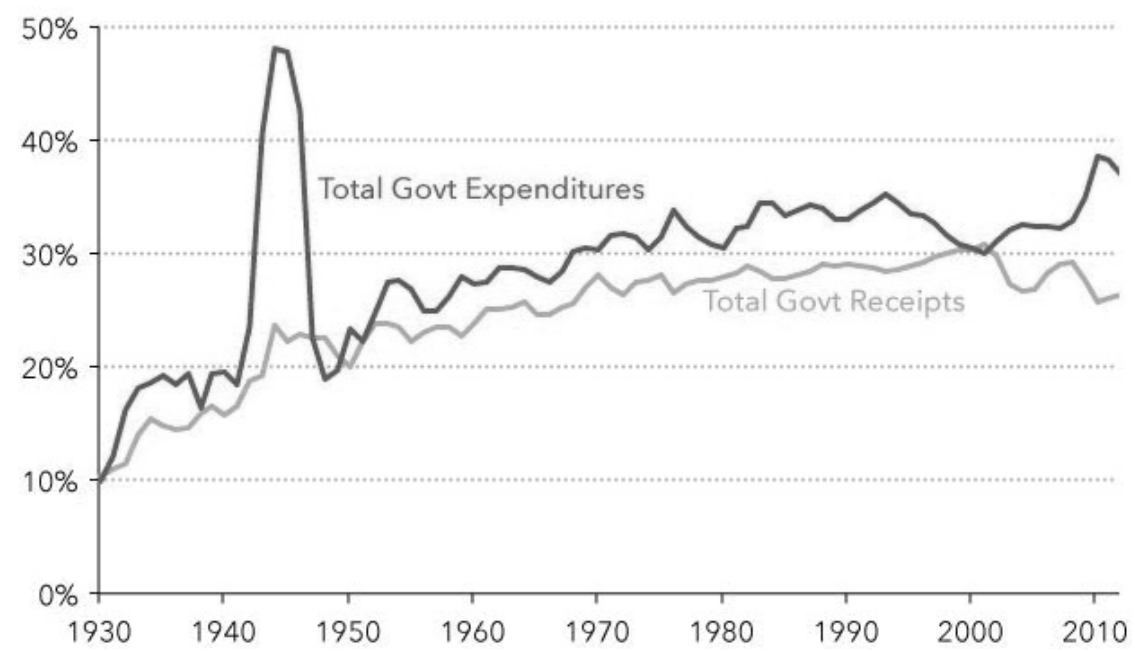

Figure 1. U.S. total government expenditures and receipts as a percentage of GDP, 1930-2012 Source: U.S. Bureau of Economic Analysis.

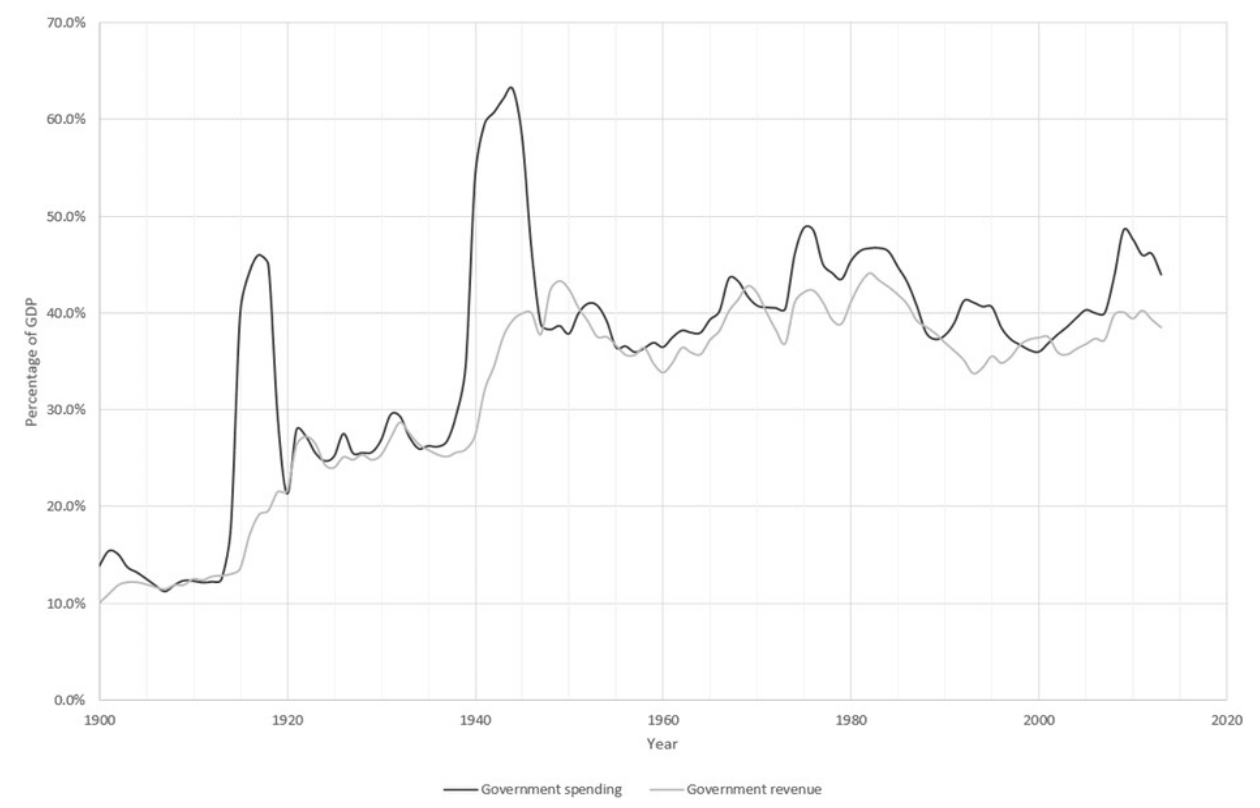

Figure 2. UK total government expenditures and receipts as a percentage of GDP since 1900 Source: The Bank of England's "Three Centuries of Data".

The natural expansion of government and the decline of this miracle can be clearly observed in Figures 1 and 2. In the last century, public expenditures as a percentage of GDP, both in the United States and the United Kingdom, have increased approximately fourfold. Both wars resulted in enormous spending increases that were not 
completely reversed at the end. The biggest decrease in U.K. tax revenues was after World War II and under the fairly liberal government of Margaret Thatcher. Spending dropped even more quickly than revenue under Thatcher, but picked up again under John Major's office. The long-run trend since 1900 has been for much more government involvement in the economy. Until the First World War, spending was generally low. In the U.S., for example, total government expenditure accounted for less than $2 \%$ of national income until 1916. These low levels of public spending were just enough for governments to be concerned with basic functions, such as maintaining order and enforcing property rights. A century later, the situation has reversed. U.S. total public spending amounts to $36 \%$ of GDP and the same indicator in the United Kingdom is $41.1 \%$. In the European Union, government spending averaged $46.9 \%$ from 2001 until 2017, reaching an all-time high of 50.1\% in 2009. The figure is even higher in France, standing at a hefty $56 \%$.

\section{The two confronting approaches of Europe}

There has been a fight between the advocates of two different ideals of the European Union (Bagus 2011): the interventionist and the liberal visions.

\section{The interventionist}

As a coalition of the statist interests of socialists, conservatives and nationalists, it aspires to see the European Union as a fortress: protectionist to the outside and interventionist on the inside. In this ideal, the center would rule over the periphery. There would be common and centralized legislation. The defenders of the socialist vision of Europe want to erect a European megastate, providing redistribution, regulation, and harmonization of legislation within Europe. The harmonization of taxes and social regulations would be carried out at the highest level. If the value-added tax is between 20 and 25 percent in the European Union, socialists would harmonize it to 25 percent in all countries. Such harmonization of social regulation is in the interest of the most protected. If German social regulations were applied to the Poles, for instance, the latter would have problems competing with the former.

This socialist vision is the ideal of the political class, the bureaucrats, the interest groups, the privileged, and the subsidized sectors who want to create a powerful central state for their own enrichment. Sovereign states would become subservient to the central state. It provides no obvious geographical limits for the European state, in contrast with the Catholic-inspired classical-liberal vision. Political competition is disregarded. In this sense, the central state becomes less and less democratic as power is shifted to bureaucrats. An example is provided by the European Commission, the executive body of the European Union. The commissioners are not elected but appointed by the member-state governments. 
The increasing detachment of the British with the EU and the ultimate Brexit decision should be understood in this line. The British position as an unconquered island nation with a long tradition of parliamentary democracy marks it out from other European nations. Fiscal policies imposed by Brussels have enormously undermined support for the Europen Union in the UK. Unfortunately, this same process of de-legitimizing the $\mathrm{EU}$ is also underway across the continent, ranging from nationalists from the French Front National to the Italian Five Star Movement or the German AFD, among others.

\section{The liberal}

The founding fathers of the EU, Schuman (France), Adenauer (Germany), and de Gasperi (Italy), all German-speaking Catholics, were followers of the classical-liberal vision of Europe. All of them were also Christian democrats. Individual liberty is the most important cultural value in the classical-liberal vision. Sovereign European states should defend private-property rights and a free-market economy in a Europe of open borders, thus enabling the free exchange of goods, services, capital, workers, technology and ideas. The Treaty of Rome was the main achievement towards the liberal vision for Europe. The treaty defended four basic liberties: free circulation of goods, free offering of services, free movement of financial capital, and free migration. The treaty restored rights that had been essential for Europe during the classical-liberal time in the $19^{\text {th }}$ century but had been abandoned in the age of nationalism and socialism at the end of the $19^{\text {th }}$ and beginning of the $20^{\text {th }}$ century.

Free competition without entry barriers should prevail in a common European market. In this vision, no one could prohibit Inditex, the Spanish retail firm, for instance, from moving to Ireland, and no one could tax a French person for transferring money from a German to an Italian bank, or for investing in the Dutch stock market. No one could prevent, through regulations, a French winemaker from selling wine in Germany. No government could give subsidies distorting competition. No one could prevent a Danish citizen from running away from his welfare state and extremely high tax rates and migrating to a state with a lower tax burden, such as Ireland. The classical-liberal vision is highly skeptical of a central European state, because it is considered detrimental to individual liberty. Many defenders of this vision are inspired by Catholicism, and the borders of the European community are defined by Christianity.

In line with Catholic social teaching, the principle of subsidiarity should prevail: problems should be solved at the lowest and least concentrated level. The only centralized European institution acceptable would be a European Court of Justice, its activities restricted to supervising conflicts between member states, and guaranteeing the basic liberties. From the liberal point of view, there should be many competing political systems, as has been the case in Europe for centuries. Before 1870, political diversity was demonstrated most clearly in the strongly decentralized Germany. Under a culture of diversity, industry and music flourished. 
Competition on all levels is essential to the classical-liberal vision. With it, product standards, factor prices and wage rates tend to converge. Capital moves where wages are low, bidding them up; workers, on the other hand, move where wage rates are high, bidding them down. Markets offer decentralized solutions for environmental problems based on private property. Tax competition fosters lower tax rates and fiscal responsibility. Competition should also prevail in the field of money. Different monetary authorities should compete in offering currencies of high quality. Authorities offering more stable currencies would exert pressure on other authorities to follow suit. This proposal was put forward by Hayek (2011): “The past instability of the market economy is the consequence of the exclusion of the most important regulator of the market mechanism, money, from itself being regulated by the market process." So long as there is competition, those currencies that are likely to depreciate in value would be driven out of existence, leading to a situation in which only currencies with stable values would remain in circulation. Hayek believed that such competition between currencies was a discovery process, which would lead to a stable non-inflationary outcome. The most important European value, liberty, is ensured by competition.

\section{Liberalism and inequality}

Nowadays, Europe is in the midst of a burning discussion about economic liberalism. The package contains the liberalization of services, lower taxes, competition, labor-market flexibility and privatizations. It is usually held that governments should proceed cautiously and be ready to reverse their policies at any point, because these reforms tend to increase inequality. A good example can be found in the labor market. In Italy, Spain, and France, the labor market is split. The young are hired with temporary contracts which offer no prospects. When the contract expires, the employer opts not to renew it, so as not to run the risk of having to convert temporary hires into permanent employees who would acquire the right never to be fired. Reforms that eliminate this duality would not only reduce unemployment but, most importantly, would favor the very poor and young workers. This is an example of a pro-market policy that favors the poor.

The saying "more market equals more injustice" is simply not true. It is exactly the opposite. If political action honestly wants to fight for the neediest members of our society, it must adopt the pursuit of competition and a system based on meritocracy. Labor-market flexibility, deregulation of the service industry, pension reforms and greater competition in the markets is not anti-equality. Such reforms shift financing from taxpayers to the users themselves and, as such, tend to eliminate rent-seeking activities by special interest groups. In fact, they tend to increase productivity by basing rewards on merit rather than on being an insider. They tend to open up opportunities for younger workers who are not yet well-connected. Pursuing pro-market reforms 
does not imply facing a trade-off between efficiency and social justice. Pro-market policies reduce rent-seeking activities and the economic privileges enjoyed by "insiders" and, in general, government-connected people.

Table 1. Inequality indicators

\begin{tabular}{|l|c|c|c|c|c|c|}
\cline { 2 - 7 } \multicolumn{1}{c|}{} & Sweden & Germany & France & UK & Italy & Spain \\
\hline Gini coefficient before T\&T & 0.432 & 0.504 & 0.516 & 0.520 & 0.524 & 0.525 \\
\hline Gini coefficient after T\&T & 0.278 & 0.293 & 0.295 & 0.360 & 0.333 & 0.345 \\
\hline Reduction of Gini coefficient & $35.6 \%$ & $41.8 \%$ & $42.8 \%$ & $30.7 \%$ & $36.4 \%$ & $34.2 \%$ \\
\hline Poverty rate before T\&T & 0.289 & 0.363 & 0.411 & 0.338 & 0.392 & 0.420 \\
\hline Poverty rate after T\&T & 0.17 & 0.168 & 0.145 & 0.179 & 0.21 & 0.227 \\
\hline Reduction of Poverty rate & $41.1 \%$ & $53.7 \%$ & $64.7 \%$ & $47 \%$ & $46.4 \%$ & $45.9 \%$ \\
\hline Top 1\% Income Share & 7.0 & 12.7 & 8.1 & 13.9 & 9.4 & n.a. \\
\hline Top 10\% Income Share* & 23.1 & 23.2 & 24.4 & 27.7 & 24.4 & 25.0 \\
\hline
\end{tabular}

Source: OECD Statistical Database (2015, 2016*).

In the Table 1 indicators, Sweden performs particularly well. The Gini coefficient before taxes and transfers (T\&T) is relatively low, at 0.432 . Taxes and transfers lead to a Gini coefficient of 0.278 for disposable income, again the lowest of our selected countries. By contrast, the U.K., Italy and Spain start out with much higher inequality in market incomes, they redistribute less, through taxes and transfers, and they end up with elevated levels of inequality in disposable incomes (Gini coefficients above 0.33). While high income inequality in the U.K. may be the deliberate result of relying on the welfare-maximising quality of free markets, high inequality in Southern Europe probably reflects the divisions and the duality in the labor market and the "lack of adequate safety nets for the youth, single mothers, and the long-term unemployed" (Hemerijck 2013, p. 235). France and Germany stand on the middle ground. Market incomes before taxes and transfers are relatively unequal (Gini coefficients of 0.50 and 0.51 , respectively); however, national welfare systems redistribute income on a large scale, resulting in Gini coefficients ( 0.29 both) that are located between Sweden, on the one hand, and Italy, Spain and the U.K., on the other.

The relative poverty rate (the share of the population whose income is below $60 \%$ of the median income) is relatively low, at $16 \%$ in Germany and $14 \%$ in France, compared to $17 \%$ in Sweden, almost $18 \%$ in the U.K. and as much as $21 \%$ in Italy and $22.7 \%$ in Spain. Since the median income may be viewed as indicative of the "normal" standard of living in a society, the relative poverty rate is usually interpreted as the share of the population that is at risk of poverty and social exclusion. The final inequality indicators in Table 1 are the income share of the top one and ten percent of income earners. Across Europe, the top one percent share closely reflects overall inequality, ranging from $7 \%$ in Sweden to almost $14 \%$ in the U.K., but it is still lower than in the U.S., at $17.4 \%$. The differences diminish considering the top ten percent share, between $23 \%$ in Sweden and Germany, at one end, and the U.K.'s $27.7 \%$ at the other. It does indicate a concentration of income and wealth in a reduced elite of society. According 
to Milanovic (2016), reducing global inequality requires fast growth of poor countries and free migration, and all are undoubtedly better achieved and preserved through free-market policies.

Market liberalization does not necessarily lead to increased social inequality. If it did, Sweden would be a less equal society than France and Germany. Nor are high levels of product and labor market regulation the best way of pursuing egalitarian results. If they were, countries like Spain, Italy and Portugal, not to mention Greece, would be the most equal societies in the EU. And they are not. It is tempting to believe that large social transfers must be the main reason to combine liberal markets with equitable social outcomes. Certainly, social expenditure in the Nordic countries is high. But it is no higher than in France, which has higher rates of income inequality (measured by Gini coefficient) and unemployment. The belief that the economic and social dimensions are incompatible is as wrong as it is widespread. One tie that binds them is education. A well-designed education system is one of the most important public goods that the modern state can provide. It has an economic pay-off, because the relationship between a country's wealth and its human capital is well established. At the same time, it is also a good social policy, because a high-quality education system is the best way to reduce inequality. Education measures are needed to support social mobility and to avoid unequal opportunities in the long run. It includes access to high-quality early education and care, as well as formal education for all, while preventing school drop-out.

Thomas Piketty is a French economist specializing in the study of inequality, and author of the book The Capital in the 21st Century. Its fundamental thesis is that the return rate of capital is higher than the GDP growth of the economy in the capitalist system. This would mean that capital owners, by appropriating their interests and capital gains, are increasingly enriching themselves (Piketty, pp. 164-199). On the other hand, the working class, receiving only wages and despite their dedication to the productive process, would be impoverished. This idea, with Marxist trace, cries out against the unfair and unequal distribution of income and wealth. It gives the impression that the mere fact of inheriting a legacy, and despite deciding to abandon productive work, will allow to live better than an honest and hard-working laborer, however he strives to produce. Piketty argues that the unequal distribution of capital amplifies inequalities in income and wealth. Curiously, as a solution, instead of defending the expansion of the capitalist order, he proposes a global tax on wealth of up to $10 \%$, which would only serve to destroy wealth and not distribute it. It would destroy wealth because the value of a company depends entirely on the business organization it has configured. Would the value of Microsoft or Google be maintained if the U.S. government decided to nationalize them? That's completely impossible. The value of these large companies would fall to zero immediately. The value of any company is justified by its ability to generate future income. The discounted value of this future income is its current value. If the government breaks the business into two or more units, or if it replaces its employees with civil servants, or if it changes working methods, any company will 
cease to be the one that it was and will become an organization without value, incapable of continuing to provide the services it had provided so far. The solution to rising inequality is not higher taxes. Most advanced industrial countries have made real gains on inequality through relatively regressive taxes that fund programs that reduce inequality (Martin and Hertel-Fernández 2014).

The thesis of Piketty is untenable. First of all, his vision is based on the past and forgets the future. For Piketty, the value of capital depends on the past savings, but not on the discounted value of the future income that will be generated. The past accumulation of capital can influence the value of a company. However, the current value depends on the expected future income. Much capital has been invested, for example, at the Spanish airport in Ciudad Real. In fact, the investment exceeded 1,100 million euros. It has a runway $4 \mathrm{~km}$ long, an industrial area of $10 \mathrm{~km}^{2}$ and a capacity to serve two million passengers per year. Unfortunately, no plane lands at the airport, no shops have been installed and the airport has no activity. The value of the airport, regardless of the capital contribution made, is null. All the money contributed to the Spanish airport of La Mancha is lost forever. There is no possible way to make a profitable investment out of it. And this is because it is incapable of generating any economic activity sustained over time. Therefore, the value of an asset depends on the ability to generate future income and not on the investment made in the past.

On the other hand, in an environment of business competence, wealth can only be maintained if the ability to serve the client continues to be demonstrated day by day. Any business mistake, any negative external change, any change in the state regulation may end up with the value of business capital. The name of the millionaires or the most important companies changes over time. The richest today were poor yesterday, while the richest of tomorrow are unknown today. Most of the inequality in Europe during the last three decades has not come from capital income, but from wage incomes (payment of supersalaries among the most highly qualified personnel). In fact, the inequality in the ownership of capital is, for all intents and purposes, almost at historic lows, even according to the data provided by Piketty. This historical reduction in capital inequality derives, according to Piketty himself, from one of the most important events of the twentieth century: the extension of ownership over one's own home.

Another serious mistake committed by Piketty comes from not considering the promised income associated to the Welfare State. If lower-class people in Europe can not accumulate financial or real assets, it is because approximately $50 \%$ of their income is appropriated by the State. Theoretically, people pay in exchange for quality public services in the field of education, health services and social subsidies. It is a serious mistake to criticize the inequality in the distribution of wealth while silencing tax depredation, which especially affects the middle and lower classes. The French economist also does not include the entrepreneurial mechanisms in the generation of wealth. In fact, Piketty aims to replace it with a regressive material equality, where all would be equally poor and miserable. 
Finally, we find evidence of pervasive errors of historical fact, opaque methodological choices, and the cherry-picking of sources to construct favorable patterns from ambiguous data (Magness and Murphy 2015). The French economist includes into the figure of capital the business benefits, the mixed-income of sole traders, the accrued real estate income and capital consumption. In the days of an estate bubble, these figures are grossly overvalued. Additional evidence suggests that Piketty used a highly distortive data assumption from the Soviet Union to accentuate one of his main historical claims about global capitalism in the $20^{\text {th }}$ century. Taken together, these problems suggest that Piketty's highly praised and historically-driven empirical work may actually be one of the book's greatest weaknesses.

\section{The rise of populism and protectionism}

Populist parties pose a threat to liberalism. In fact, populism has been on the rise for quite some time, and it is doubtful that it will go away. The inability to guarantee economic security has shaken the confidence in institutions and traditional parties, facilitating an increase in fear and triggering populism, aggravated by other threats such as mass migration. Promoting growth and employment, and better protecting those who are hurt by globalization and technology, should be the priorities. More transparency and accountability at the level of the European institutions are clearly needed. While national and EU officials have paid lip service to these ideas, they have taken little action. Algan et al. (2017) study the political consequences of the Great Recession in Europe, documenting that in post-2008 elections, EU regions experiencing higher unemployment gave more support to populists. They also document that regions where unemployment rose experienced the sharpest decline in trust in institutions and traditional politics. Dustman et al. (2017) report similar results, showing that in the aftermath of the crisis, mistrust towards European institutions (largely explained by worse economic conditions in Eurozone countries) is positively correlated with populist voting. Foster and Frieden (2017) use individual characteristics from the Eurobarometer survey data to show how the link between mistrust and populism is more pronounced in debtor countries.

One can no longer be sure whether Europe is just at a crossroads or on the verge of a precipice. The multi-faceted economic crisis has deepened without resolving the fundamental imbalances. The risks of another financial meltdown have not disappeared. Following the crisis, banking integration was reversed, and this exacerbated macroeconomic asymmetries across countries. If Europeans were as mobile as Americans, the variation in unemployment rates across euro-area countries would have declined by almost $40 \%$ (Blanchard 2018). The widespread political crisis has also been exacerbated. There is little disagreement that the European integration project needs to be reformed and that this needs to be done before the next economic downturn. The next crisis may have severe political and economic consequences if it finds Europe 
unprepared. The costs of doing nothing are enormous. Reforms are needed to ensure more efficiency, social inclusiveness and sustainability. The composition of the European Parliament has changed recently. It has experienced a shift away from the traditional left-right divide towards a new division between anti-globalization/EU (mostly populists on the extreme right and extreme left) and pro-globalization/EU (mostly liberals).

It seems that we are now witnessing the death of liberal Europe. It splits existing parties and throws up new ones. It opens new fronts between nations. Populism means politics without policies, while technocracy means policies without politics. Some nations favor liberal, European solutions, based on international cooperation, within the EU and globally. On the other hand, populist governments advocate illiberal solutions. For several years, the latter has been gaining momentum. The issue of immigration is not only symbolic, but real. More than 2 million East Europeans went to Britain after the EU's enlargement in 2004, and real concerns about housing, schools, employment and healthcare contributed to the Brexit vote. Italy, Greece and Spain have accommodated numbers of both refugees and migrants, who risk death crossing the Mediterranean. However, the populist Salvini government has pulled Italy to the far right, spreading an anti-immigrant panic.

Immigration arouses concerns on culture and identity. In a poll conducted by the Bertelsmann Foundation in 2017, an average of 50\% of respondents agree with that there are so many foreigners in their country, and they even sometimes feel like an outsider. In Italy, the figure was 71\%. Exploiting social discontent, the populists tell a simplistic story about how playing the national card and taking back domestic control will result in the restoration of good jobs and a more traditional national community. Meanwhile, the digital revolution, now advancing through machine learning towards artificial intelligence, means there will even be more disruptive change and insecurity in the workplace.

As populism has risen in many states, Germany remains the stable, liberal center of Europe. And France, with president Emmanuel Macron, is considering cutting public spending by around one hundred thousand million euros. In a world of giants, Europe must be a giant itself, or we will be trampled underfoot. And the good performance of the Franco-German axis is much needed to keep the dream of Europe alive.

In terms of free trade, the arrival of Donald Trump in the White House reflects a new era of nationalism and protectionism. President Trump has imposed tariffs on imports from Canada, Mexico and the European Union. And he plans still more tariffs on products from China in retaliation for what he calls decades of theft of American know-how. There is a clear risk of the world heading toward a trade war. And the consequences are always dismal and negative for everybody. We should remember the notorious examples of the Smoot-Hawley Act passed by U.S. Congress in 1930 that deepened the Great Depression. The law hiked U.S. tariffs by an average of 20 percent, initially to protect American farmers but then broadened to industry as well. As de- 
mand collapsed, countries devalued their currencies and imposed even more trade barriers. Global trade fell drastically. The international division of labor collapsed. This is worrisome news for Europe now. The resumption of a trade war will negatively affect production and employment, increasing prices and reducing real disposable income.

The EU reaction should be the reinforcement of the European internal market, deepening economic integration within the single market. There is a need for further abolition of technical, legal and bureaucratic barriers to free trade and free movement between the EU member countries. Competition has brought prices down and given consumers more choices, without undermining fairness or consumer protection. Economic integration is particularly needed with a recession, allowing EU countries to continue trading with one another. Resorting to protectionist measures would worsen the crisis. Many obstacles still remain to reduce separated national markets for financial services, transport and energy. Also, rules on the recognition of vocational qualifications need to be simplified to make it easier for qualified workers to find a job in another EU country. And the capital markets union should strengthen the flows of capital between EU countries.

\section{Towards a new Europe: economic integration and political disintegration}

The EU has generated growth through its single market and enlargement projects. The political disintegration of the EU should strengthen other political actors such as cities, regions or global institutions, such as the Christian church. As a result, state borders should be fuzzier, political loyalties increasingly divided and administrative jurisdictions overlap to a much greater extent. In fact, a sort of neo-medievalism. This new form of integration should have no ambition whatsoever to create a pan-European government. Integration can evolve along functional rather than territorial lines. Such diverse and decentralized integrated networks are likely to be more effective and responsive than the current EU, with its rigid rules, dysfunctional central institutions and disconnection from the concerns of citizens and markets. The aim of free integration enhances the international division of labor without losing Europe's diversity and pluralism. This mode of integration, whether in the areas of migration, transport, sport, energy or leisure, would be more capable of getting things done. Its competence would ensure its greater legitimacy.

European integration can be understood as a process of state transformation (Bickerton 2012). Member-states differ from traditional nation-states. They are not founded on the idea of popular sovereignty but rest upon the idea that the governance of domestic societies requires external frameworks of rule that can limit the decisions of domestic politicians. National authority is thus exercised through external rules and norms. Member statehood involves the existence of conflict between state and soci- 
ety rather than an identity of interests between ruler and ruled. This does not mean that states disappear, but only transform. There are other actors much more efficient than traditional and obsolete nation-states. Global companies, big cities and regions, or even Christian agencies and international organizations, become leaders in generating innovation, growth and social inclusiveness. In comparison, states fail. It refers us to the idea of a medieval Europe, with several diversified centers of authority.

We are living the demise of the nation-state. In fact, it has outlived its usefulness. The success of the European Union in creating a common economic, legal and institutional framework, as well as a common currency, have undermined the benefits of belonging to a large state. In the past, a large state meant a large market; but now, even micro-states in the EU can enjoy equal access and compete in a market of millions of people without incurring the costs of a loss of independence. Western victory in the Cold War reduced the threat of military conflict while the success of the European Common Market reduced the economic incentives offered by large nation-states. It helps explain why the parliament of Scotland approved the Act of Union in 1707, largely because the Scottish elites and emerging merchant classes were desperate to access the large and prosperous English colonial empire and markets. Or why a region like Catalonia is struggling to get outside of the political borders of a Spanish state: it is distant from the political center of Madrid, geographically part of the Western Mediterranean economic area rather than central Iberia, ethnically similar but linguistically and culturally different, and of a size and wealth to be viable in Western Europe (Franch Parella 2016).

The most competitive countries in the world are not large state-nations, but small ones. According to the World Economic Forum in its annual Global Competitiveness Report, among the countries that have topped the ranking in the last decade we can find Denmark (with flexible labor markets that protect workers' rights through high employment and low inequality), Norway (which holds high levels of communication technology and a very dynamic business sector), Finland (preparing the younger generation for the challenges of a Fourth Industrial Revolution through innovative teaching approaches), Sweden (after reducing its over-expanded welfare-state), Hong Kong (with stable financial markets and flexible labor market), the Netherlands (with a strong education system and high levels of technological expertise), Singapore (the city-state that is among the highest in the world in education and goods market efficiency) and Switzerland (the small European nation that has retained the top spot since 2012). In general, the world we used to know with nation-states negotiating, competing and clashing has become increasingly irrelevant. Soon it can become a relic of the past.

Nation-states concentrate power and distribute benefits; and the greater the degree of centralization, the greater the concentration of both power and benefits in the center. When the centralized state becomes overly extractive and corrupt, friction increases rapidly in the more distant and diverse regions. In Spain, for instance, the state is widely perceived as being corrupt, and this friction rises to the point where separation from the center is viewed as necessary by discriminated populations as Catalo- 
nia. In fact, Spain has become the very definition of the politically unresponsive, extractive state run by a minority elite. Political and economic elites divert power and wealth to themselves and are undoubtedly responsible for much lower growth than could have been achieved in a state with lower levels of corruption and less presence of crony capitalism.

\section{Conclusions}

The benefits delivered by the European Union and its forerunners have been enormous. It has raised prosperity based on open markets and fair competition. Many poorer regions have grown and recovered through unprecedented levels. The Europe based on open borders, enabling the free exchange of goods, services, capital, workers, technology and ideas, is at the cornerstone of the revival after the two global wars of the first half of the $20^{\text {th }}$ century. The Treaty of Rome was the main achievement towards a liberal Europe that stands at the forefront of world trade liberalization. The roots of the European configuration is that a civilization developed that considered itself to be a unity and yet was politically decentralized. The history of the continent devolved into a mosaic of separate and competing jurisdictions and polities, whose internal divisions resisted central control. The limits to government expansion have been a key point in what is called the "European miracle". Christian values have also decisively contributed to keeping the power at bay.

Yet Europe now faces huge challenges as it integrates and expands. Increasing political and economic centralization in Brussels raised British misgivings about the EU. Trade policy, in particular, has emerged as a new crisis, confronting the EU with US protectionism. The weight of public spending has drastically risen. To answer these challenges, Europe needs to return to classical-liberal values, protecting individual dignity and liberty, private property and free market competition, the rule of law and the fight against corruption. The more Europe suffers, the more its people will see that a reform agenda that is just an exercise in incrementalism is also nothing more than an exercise in futility.

The obsolete and dysfunctional nation-state must change and evolve to a new form of political integration, much more decentralized. A substantial part of the present European crisis has less to do with European cooperation and more to do with member states that are fragile, ineffective, and have serious corruption problems. The history of European integration also shows that giving the European Commission more powers does not necessarily prevent cheating, and that monitoring the diverse nation-states is a daunting task. The idea of "more Europe" cannot be understood simply as the dilution of the power of big member states in favor of the European Commission. The eurozone needs to take a big step into a deeper and somewhat different integration, and it needs to stimulate growth as well as austerity. There are advances in the banking union. The "big bazooka" and the quantitative easing policies may have calmed 
markets temporarily, but restoring public confidence and triggering healthy growth is a different matter altogether (Franch Parella 2018).

The European model must allow countries to have the benefits of small states that are close to the people and control all the things they care about while getting access to the economies of scale. Life moves toward plurality, independent self-constitution, diversity and self-organization. Economic integration reduces the benefits of large jurisdictions and increases the costs of holding together heterogeneous populations (Alesina and Spolaore 2003). The disintegration of the nation-states is the by-product of the European integration process itself. And Europe is populated by 250 regions, which are clearly defined by cultural, ethnic, or historical identities. New administrative and political arrangements must be discovered and dealt with. As political disintegration of the nation-state is only a matter of time, renegotiating the terms of the relationship is more beneficial than resorting to political threats or the use of force. And as small jurisdictions get their lifeblood from a large and well-functioning European market, they will be more willing than larger ones to deepen the degree of economic integration. If the $20^{\text {th }}$ century opened with the demise of liberalism and two world wars which left indelible scars on the map of Europe, the $21^{\text {st }}$ century should see the revive of liberalism with regional democratic movements replacing past great power politics.

\section{References}

Alesina, A., Spolaore, E. (2003), The size of nations, MIT Press, Massachusetts.

Algan, Y., Guriev, S., Papaioannou, E., Passari, E. (2017), The European Trust Crisis and the Rise of Populism, "Brookings Papers on Economic Activity", Fall.

Bagus, P. (2011), The Tragedy of the Euro, Terra Libertas Limited.

Berman, Harold J. (1983), The Influence of Christianity on the Development of Western Law, "The Interaction of Law and Religion", Abingdon Press, Nashville/New York. Berman, Harold J. (1983), Law and Revolution: The Formation of the Western Legal Tradition, Harvard University Press, Cambridge.

Bickerton, C. (2012), European Integration: from Nation-states to Member-states, Oxford University Press.

Blanchard, O. (2018), The Missing Third Leg of the Euro Architecture: National Wage Negotiations, PIIE.

Boettke, P. (Ed.) (1994), Collapse of Development Planning. NYU Press. Retrieved from http://www.jstor.org/stable/j.ctt9qfq37 (accessed: 15.06.2017)

Carlyle, R.W., Carlyle, A.J. (1950), A History of Medieval Political Theory in the West, Blackwood, Edinburgh.

Cubeddu, R. (1997), Atlante del liberalismo, Ideazione, Rome.

Dahrendorf, R. (1987), Liberalism, in Eatwell, Milgate, and Newman, eds., London.

Dustmann, C., Eichengreen, B., Otten, S., Sapir, A., Tabellini, G., Zoega, G. (2017), Europe's Trust Deficit: Causes and Remedies, CEPR Press. 
Foster, C., Frieden, J. (2017), Crisis of Trust: Socio-economic determinants of Europeans' confidence in government, Harvard University, Mimeo.

Franch Parella, J. (2016), La secesión como solución al problema del Estado. El caso de Cataluña, "Procesos de Mercado: revista europea de economía política", vol. XII, núm. 2, pp. 239-277, Madrid.

Franch Parella, J. (2018), Unconventional expansionary monetary policies. An economic analysis of quantitative easing, Journal of Business \& Economic Policy, Vol. 5, No. 2, pp. 22-28, Alabama.

Hall, John A. (1987), Liberalism: Politics, Ideology, and the Market, University of North Carolina Press, Chapel Hill, N.C.

Hayek, F. (2011), The denationalization of money: the argument refined, Ludwig von Mises Institute Publisher.

Hemerijck, A. (2013), Changing Welfare States, Oxford University Press.

Hoppe, Hans-Hermann (2001), Democracy: The God that Failed. The Economics and Politics of Monarchy, Democracy, and Natural Order, Transaction, New Brunswick, N.J.

Magness, P., Murphy, R. (2015), Challenging the Empirical Contribution of Thomas Piketty's Capital in the $21^{\text {st }}$ Century, Journal of Private Enterprise, GMU School of Public Policy Research Paper No. 15-2. Available at SSRN: https://ssrn.com/abstract $=2543012$

Martin, C. J., Hertel-Fernández, A. (2014), How Sweden fights inequality without soaking the rich, VOX. Available at: https:/www.vox.com/2014/10/8/6946565/progressive-taxes-are-not-the-solution-to-inequality (accessed: 18.03.2016).

Merquior, José G. (1991), Liberalism Old and New, Twayne, Boston.

Milanovic, B. (2016), Global Inequality: a new approach for the age of globalization, Harvard University Press, Boston.

Mises, L. (2007). Theory and History: an interpretation of social and economic evolution. Ludwig von Mises Institute Publisher.

Piketty, T. (2014), Capital in the Twenty-First Century, Harvard University Press, Cambridge.

Stewart, D. (1966), Biographical Memoir of Adam Smith, Augustus M. Kelley, New York.

Weber, M. (1949), The Methodology of the Social Sciences, Edward A. Shils and Henry A. Finch (trs. and eds.), Free Press, Glencoe, Illinois. 


\section{Streszczenie}

\section{Upadek liberalizmu w Europie i sposoby jego ożywienia}

Liberalny porządek świata przyniósł ogromne korzyści Europie i ludziom na całym świecie. Mający swe początki w XVIII i XIX wieku liberalizm wzmacniał naturalne prawa człowieka do życia, wolności i własności i przekształcał świat w sposób, który umożliwił poprawę materialnych i społecznych warunków życia ludzkości. Ale liberalny porządek, który istnieje w Europie od 1945 roku, po dwóch wojnach światowych, zaczął ulegać rozpadowi. Obecnie ten liberalny porządek poddawany jest różnym siłom. Istotą europejskiego doświadczenia jest rozwój cywilizacji, która uważała się za jednolitą całość, a mimo to ulegała politycznej decentralizacji. Dawne wolne miasta we Włoszech i w Niderlandach stały się bastionami samorządowej klasy średniej w średniowieczu. Jednak z czasem państwa mają tendencję do rozrostu, pozyskują coraz więcej zasobów, co skutkuje wzrostem podatków i wydatków publicznych, nadmierną regulacją, powstawaniem deficytów i długu publicznego. Dochodzi do konfliktu między zwolennikami dwóch różnych wizji Unii Europejskiej: nieliberalnej i liberalnej. Istnieje konsensus, że gospodarka rynkowa jest systemem, który jest najbardziej efektywny i przyczynia się do wyjścia milionów ludzi z ubóstwa. Ale to właśnie nierówny podział wytworzonego bogactwa jest często krytykowany. Zbadano rozkład dochodów przed opodatkowaniem, po opodatkowaniu i transferach kapitałowych, dochodząc do wniosku, że liberalizacja rynku niekoniecznie prowadzi do wzrostu nierówności społecznych. Z drugiej strony, dwa z najważniejszych zagrożeń stanowiących wyzwanie dla liberalnego porządku w Europie to partie populistyczne i protekcjonizm. Wreszcie, autorzy artykułu sugerują drogę ku przyszłej Europie, opartej o pogłębienie jednolitego rynku i integrację gospodarczą, ale dążącej do przekształcenia nieaktualnych i dysfunkcyjnych państw narodowych w inne, zdecentralizowane byty polityczne.

Słowa kluczowe: liberalizm, Europa, jednolity rynek, państwo narodowe, decentralizacja 